\title{
EFEKTIVITAS INDUKSI REPRODUKSI Macrobachium Rosenbergi BETINA DENGAN KOMBINASI ABLASI UNILATERAL DAN SUPLEMENTASI VITAMIN E
}

\section{EFFECTIVENESS OF INDUCED BY FEMALE REPRODUCTIVE MACROBACHIUM ROSENBERGI COMBINATION OF ABLATION UNILATERAL AND VITAMIN E SUPPLEMENTATION}

\author{
Inayatsyah ${ }^{1}$ Rahmawati Nasution ${ }^{2}$ \\ ${ }^{1}$ Program Studi Perikanan, Fakultas Perikanan dan Ilmu Kelautan, Universitas Teuku Umar \\ ${ }^{2}$ Fakultas Biologi, Universitas Jenderal Soedirman \\ Korespondensi: inayatsyah@utu.ac.id
}

\begin{abstract}
This study aims to Know the optimum dosage of vitamin E supplementation on feed for a long time ripe gonads, IKG, fecundity egg and larval survival on prawns female, And Knowing the optimum dose vitamin E supplementation on feed for a long time ripe gonads, IKG, fecundity eggs and larval survival in female prawns were ablated unilateral. This research was carried out experimentally, with the experimental design basic design completely randomized (CRD) factorial $2 \times 4$, consists of two factors: Prawn females ablation, consists of two levels: Prawns females without ablation (UGT), Prawns female ablation unilateral (UGA). The dose of vitamin E / $\mathrm{kg}$ feed, consisting of four levels: Vitamin E $0 \mathrm{IU} / \mathrm{kg}$ feed, vitamin E $200 \mathrm{IU} / \mathrm{kg}$ feed, vitamin E $400 \mathrm{IU} / \mathrm{kg}$ feed, vitamin E $600 \mathrm{IU} / \mathrm{kg}$ feed. The optimum dosage vitamin E supplementation of $600 \mathrm{IU}$ on feed effective Time ripe for a review of the old gonads, IKG , egg fecundity and the degree of continuity of Life larvae prawns females. Supplementation of vitamin E at 200 IU at prawn the ablated females showed a unilateral already fecundity best eggs. Induction reproductive females with a combination of prawns unilateral ablation and vitamin E supplementation of $600 \mathrm{IU}$ on feed effectively improve reproduction prawns.
\end{abstract}

Keywords: Ablation, M.Rosenbergi, Reproduksi, Vitamin E

\section{Pendahuluan}

Udang sebagai salah satu komoditas perikanan yang sangat populer dan memiliki nilai ekonomis tinggi dalam perdagangan internasional (Hadie et al., 2001). Prospek pasar yang cerah, bernilai ekonomis serta memberikan keuntungan ini perlu diimbangi dengan ketersediaan pasokan benih. Kementerian Kelautan dan Perikanan (KKP) terus menggerakkan seluruh potensi perikanan untuk kesejahteraan rakyat.

Salah satu potensi yang menjadi prioritas dari kebijakan KKP adalah udang. Sebagai komoditas unggulan KKP, produksi udang ditargetkan meningkat sebesar $15 \%$ dari tahun 2011 sebesar 460 ribu ton menjadi 529 ribu ton pada tahun 2012 (Subyakto dan Sakti, 2012). Pemenuhan permintaan pasar terhadap udang diperoleh dari hasil penangkapan dan budidaya, tetapi masih dalam jumlah terbatas. Hal ini memberikan peluang untuk meningkatkan produksi budidaya udang. Potensi produksi akan kebutuhan udang ini harus didukung, salah satunya adalah dengan program pemuliaan selektif untuk meningkatkan pertumbuhan, reproduksi dan ketahanan terhadap penyakit. 
Udang galah (Macrobrachium rosenbergii De Man, 1879) merupakan komoditas perikanan air tawar yang potensial untuk dibudidayakan secara komersial. Udang galah yang merupakan udang air tawar berukuran terbesar di antara udang air tawar lainnya dapat dijadikan alternatif lain selain udang Penaeid dan Vannamei. Pertumbuhan yang cepat, ukuran yang besar, tingkat prevalensi penyakit yang rendah dan permintaan pasar yang luas, merupakan potensi yang menjadikan komoditas ini memegang peranan penting dalam usaha budidaya perikanan air tawar di Indonesia (Hadie et al., 2001).

Permintaan akan udang galah ini terus menerus meningkat pada eranya, tetapi tidak dibarengi dengan produksi yang meningkat. Padahal budidaya udang galah menjadi alternatif pilihan ketika udang Penaeid mulai mengalami permasalahan (Ali, 2001). Kendala yang dihadapi adalah ketersediaan benih alam. Alam tidak akan mampu memenuhi seluruh kebutuhan benih udang. Hal ini mengakibatkan kesulitan memperoleh benih dalam jumlah dan ukuran yang ideal pada waktu yang tepat, sehingga diperlukan upaya penyediaan induk yang matang gonad dan siap untuk dipijahkan. Selain hal tersebut, permasalahan yang kerap kali muncul dalam produksi benih adalah kualitas benih yang rendah seperti daya tetas telur dan tingkat kelangsungan hidup larva yang rendah (Racotta et al., 2003). Saat pemijahan, hanya sekitar $30-40 \%$ dari induk betina udang galah yang siap untuk bertelur. Solusinya adalah dengan sinkronisasi pematangan ovarium melalui manipulasi hormon atau lingkungan (Bindu et al., 2010). Pematangan gonad udang galah dapat dilakukan dengan cara induksi melalui manipulasi hormon dengan teknik ablasi mata, rekayasa pakan dan pendekatan lingkungan (Siahainenia et al., 2008). Salah satu cara yang efektif untuk meningkatkan produksi benih udang dapat dilakukan dengan teknik ablasi ataupun perbaikan melalui pakan.

Ablasi tangkai mata udang merupakan upaya untuk meningkatkan pemenuhan produksi benih udang dengan prinsip mempercepat kematangan gonad. Ablasi dilakukan sebagai upaya untuk menghilangkan organ $\mathrm{X}$ yang ada ditangkai mata. Organ $\mathrm{X}$ menghasilkan hormon penghambat perkembangan dan pematangan gonad (Gonad Inhibiting Hormone/GIH) serta penghambat pergantian kulit (Moulting Inhibiting Hormone/MIH). Ablasi mata pada krustasea merupakan cara yang cepat dan murah untuk merangsang proses pemasakan telur. Ablasi unilateral merupakan pemotongan satu tangkai mata, pemotongan ini efektif dapat mengurangi mortalitas induk yang diablasi dan dapat mempercepat kematangan gonad pada udang (Siahainenia et al., 2008).

Peningkatan jumlah betina molting dalam kelompok ablasi terjadi setelah enam minggu pasca ablasi menunjukkan pematangan kembali setelah pemijahan.Peningkatan produksi dan kualitas sel telur juga dapat dilakukan melalui peningkatan kualitas pakan induk. Pengkayaan pakan pada induk merupakan hal penting dilakukan untuk memperbaiki kualitas telur yang dihasilkan (Suwoyo et al., 2001). Reproduksi induk udang tidak akan sempurna jika pasokan nutrisinya tidak memenuhi persyaratan (Yuwono, 2005). 
Kekurangan vitamin E dapat memperlambat kematangan gonad, daya tetas dan kelangsungan hidup yang rendah pada ikan (Izquierdo et al., 2001). Pemberian pakan dengan konsentrasi vitamin E $475 \mathrm{mg} / \mathrm{kg}$ pakan menunjukkan hasil yang optimum untuk meningkatkan fekunditas ikan zebra betina prasalin (Utomo et al., 2006). Begitu pula hasil penelitian pada ikan patin yang dilakukan oleh Yulfiperius (2001) menunjukkan bahwa pakan yang mengandung 189,65 mg VE/kg pakan menghasilkan tingkat penetasan yang tinggi (78,77\%), jumlah total larva 332,339 ekor/kg induk, dan larva abnormal terendah $(0,19 \%)$. Oleh sebab itu, penggunaan vitamin E pada beberapa spesies ikan menyebabkan proses reproduksi yang lebih sempurna (Tridjoko et al., 2001), tetapi penelitian ini lebih banyak dilakukan pada ikan, sedangkan kajian mengenai hal tersebut masih jarang dilakukan pada udang galah. Bertitik tolak pada permasalahan tersebut maka dilakukan penelitian untuk mengkaji efektivitas induksi reproduksi Macrobrachium rosenbergii betina dengan kombinasi ablasi unilateral dan suplementasi vitamin E pada pakan terhadap lama waktu matang gonad, Indeks Kematangan Gonad (IKG), fekunditas, dan Tingkat Kelangsungan Hidup (Survival Rate (SR) larva.

\section{Metode Penelitian}

Penelitian ini dilakukan secara eksperimental, dengan rancangan percobaan Rancangan dasar Acak Lengkap (RAL) pola faktorial 2 x 4, terdiri atas 2 faktor Udang Galah Betina Ablasi, terdiri atas 2 taraf : Udang galah betina tanpa ablasi (UGT). Udang galah betina ablasi unilateral (UGA). Dosis vitamin E/kg pakan, terdiri atas 4 taraf : Vitamin E 0 IU/ kg pakan. Vitamin E $200 \mathrm{IU} / \mathrm{kg}$ pakan Vitamin E $400 \mathrm{IU} / \mathrm{kg}$ pakan Vitamin E $600 \mathrm{IU} / \mathrm{kg}$ pakan. Perlakuan penelitian terdiri atas 8 perlakuan. Setiap perlakuan diulang 9 kali, sehingga total unit penelitian 9 × $8=72$.

Materi yang digunakan adalah induk betina udang galah yang berasal dari Loka Riset Pemuliaan dan Teknologi Budidaya Perikanan Air Tawar, Sukamandi, Jawa Barat, berjumlah 72 ekor dengan bobot rerata $38 \mathrm{~g}$, induk udang galah jantan 24 ekor, vitamin E alpha tocopherol, alkohol 70\%, aquades, tepung kanji, iodine, methylene blue, pakan komersil dan artemia. Peralatan yang digunakan meliputi 8 kolam pemeliharaan induk berukuran $2 \mathrm{~m} \times 1 \mathrm{~m} \times 0,5 \mathrm{~m}$, wadah penetasan, aerator, selang siphon, timbangan, mangkok/piring plastik, sprayer, cawan petri, gelas ukur, gunting/peralan bedah, bunsen, termometer, $\mathrm{pH}$ meter, DO meter, refraktometer, mikroskop dan kamera. Pengambilan data diperoleh dari 9 ulangan yang disediakan, 3 ulangan masing-masing diperuntukkan bagi perhitungan IKG, fekunditas telur dan kelangsungan hidup larva. Data lama waktu matang gonad diperoleh dari seluruh individu yang diamati. Parameter data pendukung meliputi frekuensi molting, pertumbuhan mutlak dan kualitas air.

Data yang diperoleh untuk mengetahui dosis optimum suplementasi vitamin $\mathrm{E}$ meliputi lama waktu matang gonad, IKG, fekunditas telur dan kelangsungan hidup larva pada udang galah betina tanpa ablasi dan ablasi unilateral, serta kombinasi antara udang galah betina yang diablasi unilateral dan diberi suplementasi vitamin E. Seluruh data tersebut dianalisis dengan two way Analiysis of Variance (ANOVA) menggunakan 
Software SPSS versi 17.0 Windows. Sebelum dianalisis secara statistik, data dalam bentuk persen terlebih dahulu ditransformasi ke dalam bentuk arsin $\sqrt{ } \%$. Hasil analisis yang berbeda nyata dilanjutkan dengan uji beda jarak nyata Duncan (BJND).

\section{Hasil dan Pembahasan}

Hasil pengamatan udang galah pasca perlakuan yang mengalami perubahan warna dan volume gonad pada cephalothorax, terbukti menunjukkan tanda matang gonad. Ovarium berwarna orange menyala dan volumenya berkembang ke arah cephalothorax (Gambar 1). Semua udang pada perlakuan udang galah betina tanpa ablasi dan diberi suplementasi vitamin E mengalami matang gonad. Jumlah udang yang matang gonad yaitu berjumlah 36 ekor.

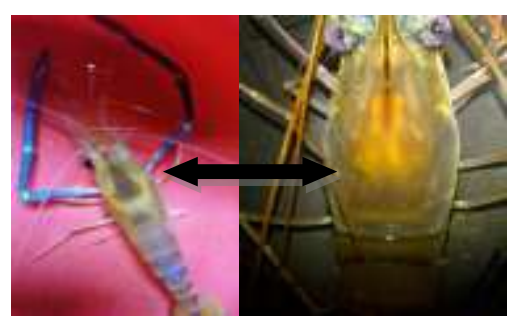

Gambar 1. Udang Galah Betina (Macrobrachium rosenbergii De Man, 1879) matang gonad.

Keterangan:

Kiri : Udang Galah suplementasi vitamin E pada pakan dengan dosis 600 IU (UGT 6)

Kanan : Udang Galah ablasi suplementasi vitamin E pada pakan dengan dosis 600 IU (UGA 6)

Minggu pertama pasca perlakuan, hanya udang galah betina tanpa ablasi dan suplementasi vitamin E 600 IU (UGT 6) yang matang gonad sebanyak 1 ekor. Matang gonad terbanyak mulai terjadi pada minggu ke-3 hingga ke-5. Minggu ke-8 terjadi periode pematangan kedua pada perlakuan udang galah betina tanpa ablasi dan suplementasi vitamin E 400 IU (UGT 4) sebanyak 1 ekor (Gambar 3.3). Dosis vitamin E 600 IU memberikan nilai rerata lama waktu matang gonad yang tertinggi pada udang galah betina tanpa ablasi (UGT 6) yaitu sebanyak 1,25 ekor $\pm 0,71$. Berturut-turut diikuti perlakuan udang galah suplementasi vitamin E pada pakan dengan dosis $400 \mathrm{IU}$ (UGT 4) sebanyak 1,25 ekor $\pm 0,71$ terendah pada perlakuan udang galah suplementasi vitamin E pada pakan dengan dosis 200 IU dan 0 IU (UGT 2 dan UGT 0) yaitu sebanyak 1,13 ekor $\pm 0,83$ ). Hasil analisis ragam menunjukkan bahwa lama waktu matang gonad udang galah tanpa ablasi dan diberi suplementasi vitamin E tidak memberikan pengaruh $(P>0,05)$. Hasil pengamatan Indeks Kematangan Gonad (IKG), merupakan salah satu indikator kematangan reproduksi udang galah betina. Pengamatan IKG dilakukan pada saat udang telah mengalami matang gonad dilihat dari warna dan volume gonadnya (Gambar 2). 


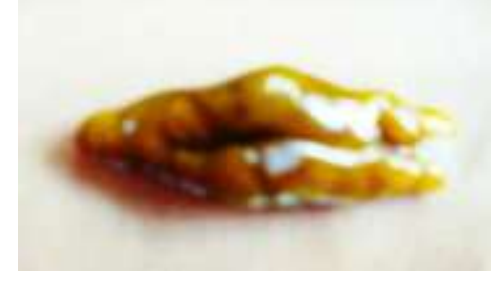

Gambar 2. Gonad udang galah (Macrobrachium rosenbergii De Man, 1879) betina perlakuan tanpa ablasi dan suplementasi vitamin E 600 IU.

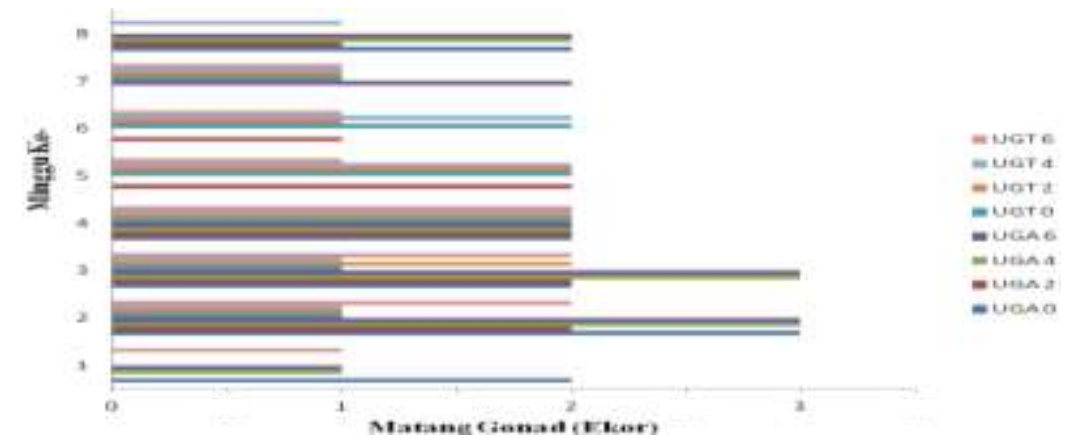

Gambar 3 Jumlah udang galah (Macrobrachium rosenbergii De Man, 1879) matang gonad hasil perlakuan kombinasi ablasi unilateral dan suplementasi vitamin E.

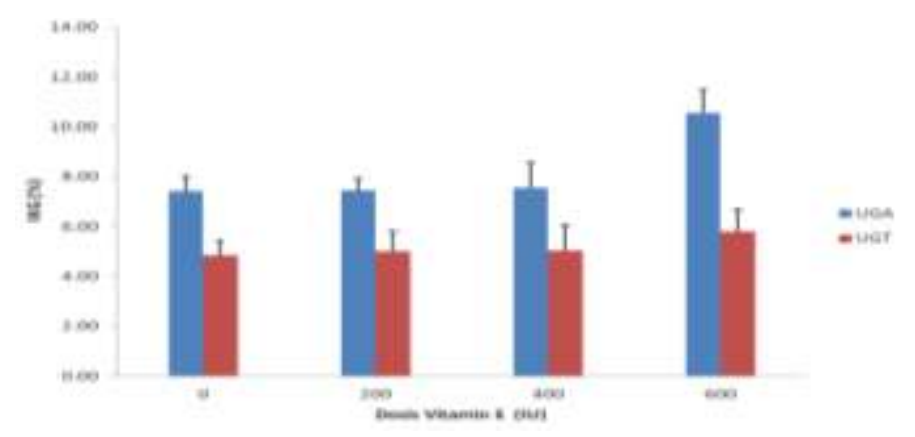

Gambar 4. Rerata IKG udang galah (Macrobrachium rosenbergii De Man, 1879) perlakuan kombinasi ablasi unilateral dan suplementasi vitamin E. 


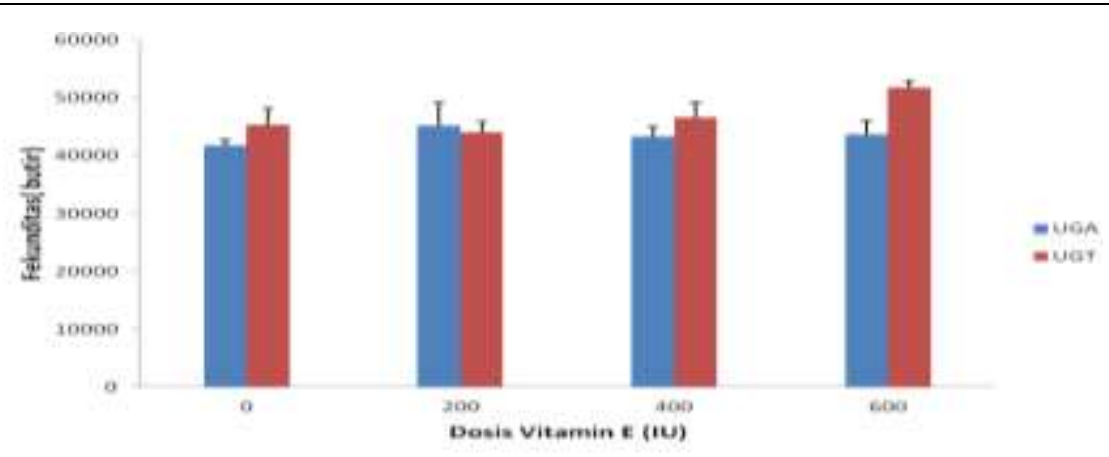

Gambar 5. Rerata fekunditas telur udang galah (Macrobrachium rosenbergii De Man, 1879) perlakuan kombinasi ablasi unilateral dan suplementasi vitamin E.

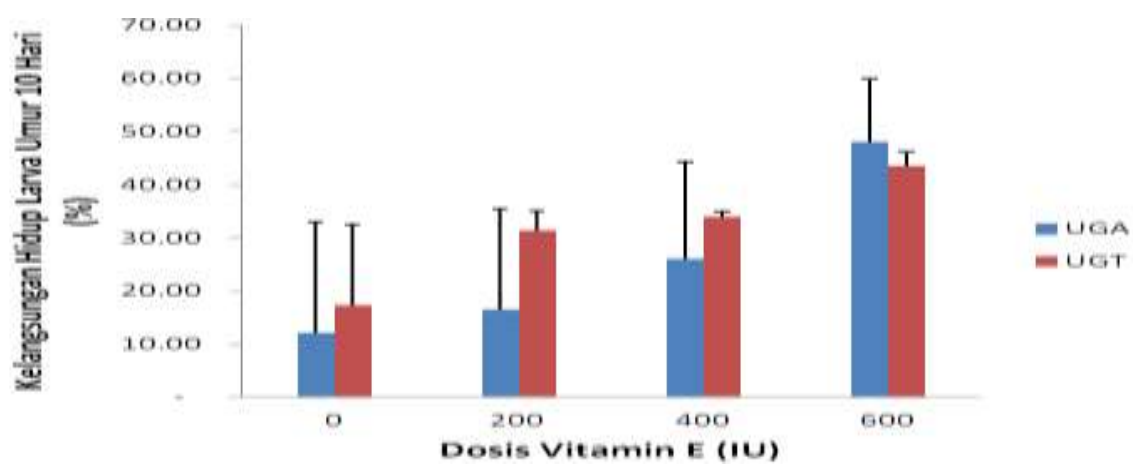

Gambar 6. Rerata kelangsungan hidup larva umur 10 hari udang galah (Macrobrachium rosenbergii De Man, 1879) perlakuan kombinasi ablasi unilateral dan suplementasi vitamin E.

\subsection{Pembahasan}

Dosis optimum suplementasi vitamin E 600 IU memberikan hasil yang efektif pada reproduksi induk udang galah betina. Hal ini terjadi baik pada perlakuan udang galah betina tanpa ablasi, ablasi unilateral, ataupun kombinasi keduanya. Hal ini terbukti pada hasil penelitian yang dilakukan bahwa perlakuan ablasi unilateral dapat mempercepat waktu matang gonad udang galah. Pada minggu pertama setelah ablasi sudah ada yang mengalami matang gonad sebanyak 4 ekor, sedangkan pada perlakuan vitamin hanya ada satu ekor yang matang gonad yaitu udang galah tanpa ablasi dan suplementasi vitamin E 600 IU (UGT 6). Pada perlakuan ablasi, matang gonad terbanyak terjadi pada minggu ke-2 yakni sebanyak 11 ekor. Sedangkan pada perlakuan suplementasi vitamin E pada pakan, matang gonad terbanyak terjadi pada minggu ke-2 yakni sebanyak 8 ekor (Gambar 3).

Waktu matang gonad tercepat pada perlakuan suplementasi vitamin E diperoleh pada dosis vitamin E 400 IU dan 600 IU, sedangkan pada perlakuan ablasi unilateral diperoleh pada dosis 600 IU. Kombinasi yang efektif untuk memcepat lama waktu matang gonad yaitu perlakuan udang galah ablasi unilateral dan suplementasi vitamin $\mathrm{E}$ 600 IU (UGA 6). Akibat dari waktu matang gonad yang lebih cepat, sehingga terjadi 
periode matang gonad selanjutnya yang lebih singkat. Hal ini terjadi pada perlakuan udang galah ablasi unilateral dan diberi suplementasi vitamin E. Hal ini sesuai laporan Okumura (2007) bahwa ablasi unilateral mempercepat kematangan gonad udang galah yakni mencapai waktu 12 hari. Santos (1998) menyatakan bahwa ablasi unilateral meningkatkan udang galah matang gonad dan mengurangi waktu antara tiap memijah. Betina dapat memijah 20 hari setelah ablasi dan memijah lagi setelah 30 hari kemudian.

Perlakuan suplementasi vitamin E membutuhkan waktu yang lebih lama bila dibandingkan dengan perlakuan ablasi unilateral. Pada penelitian ini suplementasi vitamin E tidak memberikan pengaruh $(P=0,80)$ pada lama waktu matang gonad udang. Perlakuan kombinasi ablasi unilateral dan suplementasi vitamin E pada pakan juga tidak memberikan pengaruh $(P=0,58)$. Kemungkinan kurang efektifnya vitamin $\mathrm{E}$ adalah dikarenakan cara pemberian yaitu karena vitamin yang disemprot pada pakan leaching ke dasar perairan saat pemberian makan, sehingga tidak memberikan pengaruh. Udang galah melakukan perkawinan setelah pergantian kulit pertama (prematting molt) pasca perlakuan yang diikuti matang gonad. Lama waktu matang gonad menjadi penting untuk mempercepat terjadinya proses perkawinan, sehingga efisiensi waktu pada kegiatan budidaya dapat tercapai

IKG merupakan indikator dari tahapan perkembangan udang. IKG tertinggi pada penelitian ini diperoleh pada perlakuan udang galah ablasi dan suplementasi vitamin $\mathrm{E}$ $600 \mathrm{IU}$ (UGA 6) yaitu sebesar 10,55 \% $\pm 0,94$. Kombinasi antara perlakuan ablasi dan suplementasi vitamin E pada pakan memberikan pengaruh $(P=0.046)$ terhadap IKG udang galah. Hal ini menunjukkan bahwa kombinasi antara perlakuan ablasi dan suplementasi vitamin E efektif bagi peningkatan IKG udang galah betina. Penelitian sejenis yang dilakukan menunjukkan terjadi peningkatan IKG $M$. rosenbergii yang diablasi 7,90\% $\% 0,10$ dan tanpa ablasi 5,03 \% $\pm 0,10$ (Murmu et al., 2007). Hal ini menunjukkan adanya efek positif dari ablasi unilateral pada pematangan ovarium.

Peningkatan nilai IKG pada udang yang diablasi mengindikasikan terjadinya peningkatan aktifitas reproduksi yang diakibatkan penghilangan GIH pada organ X di tangkai mata. Hal ini mempercepat perkembangan gonad, dimana pada tangkai mata mengandung faktor penghambat gonad yang pasokannya berhenti setelah diablasi, sehingga meningkatkan aktivitas kinerja gonad. Menurut Naoaki et al (2005), vitellogenin meningkat ketika nilai IKG meningkat. Pola naik turun ini dikarenakan adanya proses previtellogenesis, vitellogenesis dan akhir vitellogenesis (Affandi dan Tang, 2001). Proses vitelogenesis mengindikasikan bahwa akumulasi vitellin dalam oosit bertahap meningkat selama tahapan perkembangan ovarium. Penelitian Revathi et al.,(2012) menunjukkan isi vitellogenin meningkat awal siklus reproduksi pada tahap III dan kemudian menurun. Hal ini sesuai dengan nilai IKG yang meningkat seiring tahapan perkembangannya.

Beberapa penelitian menunjukkan nilai IKG yang beragam. Pervaiz Ahmed Pervaiz, et al. (2011) menyatakan terdapat peningkatan indeks ovarium dan diameter oosit pada perkembangan gonad M.dayanum dibandingkan dengan udang kontrol. IKG udang kontrol sebesar $0,91 \% \pm 0,21$ dan yang diablasi $2,856 \% \pm 1,11$. Umaporn et al. 
(2011) melaporkan terjadi peningkatan kematangan gonad selama peride waktu setelah udang diablasi.

Suplementasi vitamin E dalam pakan memiliki peran penting dalam pertumbuhan, sintasan dan proses pematangan gonad (Cahu et al., 1991). Cavalli et al. (2001) mendeteksi peningkatan tajam dari vitamin E dalam ovarium M.rosenbergii selama perkembangan gonad awal dari tahap I hingga III. Umumnya nilai IKG udang yang diablasi lebih tinggi dari yang tidak diablasi dan suplementasi vitamin E dalam pakan juga mempengaruhi nilai IKG. Jika membandingkan dengan penelitian Murmu et al.2007, IKG pada penelitian ini memiliki nilai lebih besar, selisih 2,65\% $\pm 0,84$. Hal ini dapat disebabkan pengaruh suplementasi vitamin $\mathrm{E}$ pada pakan, sehingga aktifitas reproduksi semakin optimal. Nilai IKG pada penelitian ini semakin tinggi seiring dengan peningkatan dosis vitamin $\mathrm{E}$ yang diberikan.

Penghitungan fekunditas penting untuk mengetahui kemampuan reproduksi udang (Nazari et al., 2003). Induksi reproduksi dengan kombinasi ablasi unilateral dan suplementasi vitamin $\mathrm{E}$ pada pakan memberikan peningkatan jumlah fekunditas telur udang galah $(P=0,47)$. Perlakuan udang galah tanpa ablasi dan suplementasi vitamin $\mathrm{E}$ 600 IU (UGT 6) sebanyak 51824 butir \pm 1132 memberikan nilai paling baik, namun pada perlakuan kombinasi nilai terbaik pada perlakuan udang galah ablasi unilateral dan suplementasi vitamin E 200 IU (UGA 2) $=45228$ butir \pm 3867 . Jika membandingkan dengan standar SNI 01- 6486.1-2000, fekunditas telur (butir/g bobot tubuh) berkisar antara 30.000-75.000, maka fekunditas telur penelitian ini sesuai dengan standar. Terdapat korelasi positif antara berat badan induk udang betina dengan jumlah telur yang dihasilkan (Fulford et al., 2012). Semakin berat udang, jumlah telur yang dihasilkan juga lebih banyak (Abowei dan Deekae, 2010). Hal ini terlihat pada perlakuan udang galah ablasi unilateral dan suplementasi vitamin E 200 IU (UGA 2), terdapat bobot udang yang lebih besar sehingga berpengaruh terhadap fekunditasnya yang semakin besar.

Fekunditas udang galah dapat dipengaruhi oleh beberapa faktor diantaranya ukuran induk, indeks kematangan gonad dan diameter oosit (Racotta et al., 2003). Fekunditas setiap induk udang berbeda-beda tergantung dari umur, ukuran dan ketersediaan makanannya. Fekunditas dari seekor induk udang galah dapat diperkirakan berdasarkan berat tubuhnya. Umumnya antara berat tubuh dan jumlah telur adalah 1 berbanding 1000 (Hadie dan Supriyatna, 1984). Rao (1991) memperkirakan fekunditas M.rosenbergii berkisar antara 20.000 dan 70.000 telur. Kisaran fekunditas mutlak yang dihasilkan yaitu 180-5800 telur (Abowei dan Deekae, 2010). Penelitian Jufri et al., 1993 bahwa suplementasi vitamin E sebesar $1 \%$ pada udang windu memberikan pemijahan, jumlah telur, dan daya tetas telur yang lebih baik daripada $0,1 \%$ dan $0,5 \%$.

Lawrence (1992) melaporkan bahwa ablasi mengakibatkan fekunditas berkurang dan penetasan yang lebih rendah dari waktu ke waktu. Ablasi pada Penaeus schmitti menyebabkan penurunan fekunditas. Jika menghubungkan dengan beberapa penelitian yang menyatakan bahwa fekunditas udang yang diablasi tidak berpengaruh secara signifikan, hal tersebut tidak terjadi pada penelitian ini. Penggunaan suplementasi 
vitamin E pada pakan memberikan kontribusi bagi peningkatan reproduksi udang galah yang diablasi. Sejalan dengan pernyataan Izquierdo et al.(2001) bahwa konsentrasi vitamin E yang tinggi diperkirakan dapat mengurangi persentase telur abnormal dan meningkatkan fekunditas telur. Diduga dengan semakin tinggi vitamin E dalam pakan semakin banyak telur yang berhasil dipertahankan dari kerusakan proses oksidasi (Halver 1989). Perbedaan hasil yang terjadi ini dapat dikarenakan pula penggunaan ukuran, umur serta lokasi sumber induk yang berbeda.

Pasca perlakuan, larva yang baru menetas kemudian dipelihara. Larva yang baru menetas masih memiliki cadangan makanan didalam tubuhnya berupa kuning telur yang akan habis pada waktu larva itu berumur 2 hari. Menurut Lavens et al., (2002) larva yang baru menetas mulai makan zooplankton 1 hari setelah menetas. Pada penelitian ini larva diberi pakan Artemia. Artemia memiki ukuran yang sesuai dengan bukan mulut larva udang galah dan memiliki nutrisi yang tinggi.

Dosis optimal suplementasi vitamin E sebesar 600 IU meningkatkan kelangsungan hidup larva umur 10 hari pada udang galah betina tanpa ablasi dan udang galah yang diablasi unilateral. Kombinasi yang efektif untuk meningkatkan kelangsungan hidup larva diperoleh pada perlakuan udang galah ablasi unilateral dan suplementasi vitamin $\mathrm{E}$ 600 IU (UGA 6) sebesar 47,95 \% 1 11,93. Menurut DKP (2009) kelangsungan hidup larva hingga juvenil muda di atas 25\%. Kelangsungan hidup terendah terjadi pada perlakuan udang galah ablasi unilateral tanpa suplementasi vitamin E (UGT 0) yaitu sebesar $12,06 \% \pm 20,88$. Faktor yang menjadi penyebab rendahnya kelangsungan hidup dapat dikarenakan kualitas air serta tempat pemeliharaan yang tidak sesuai. Bak pemeliharaan larva yang baik adalah bak fiber atau bak semen (DKP, 2009), sedangkan pada penelitian tempat pemeliharaan yang digunakan adalah baskom plastik.

Hasil penelitian Cavalli et al., (2003) menunjukkan bahwa toleransi larva yang baru menetas cenderung meningkat dengan meningkatnya tingkat vitamin $\mathrm{C}$ dan $\mathrm{E}$. Konsentrasi vitamin E yang tidak cukup dapat mengurangi jumlah pemijahan, keberhasilan penetasan telur dan kelangsungan hidup larva (Watanabe, 1988). Hal ini terbukti dengan hasil penelitian, perlakuan suplementasi vitamin E pada pakan menunjukkan nilai kelangsungan hidup yang lebih besar dibandingkan dengan tanpa suplementasi vitamin E. Selaras dengan pernyataan Vismara et al.(2003) dalam Ogbonna (2009), suplementasi vitamin E pada pakan dapat mengakibatkan kelangsungan hidup pada udang.

Pakan artemia yang diberikan diduga berlebih, sehingga menyebabkan kualitas air tidak begitu baik. Ling (1969) menyatakan bahwa perubahan stadia pada larva udang galah dipengaruhi oleh beberapa faktor, yaitu kualitas dan kuantitas makanannya. Kualitas air, penyakit, ukuran atau komposisi pakan larva menjadi hal yang perlu diperhatikan pada tahapan pemeliharaan larva udang galah (New, 2002). Kelebihan pakan dapat menyebabkan buruknya kualitas air, sedangkan kekurangan pakan dapat menyebabkan kurangnya asupan makanan pada larva, pertumbuhan yang lambat, kanibalisme dan akhirnya menyebabkan tingkat kelangsungan hidup yang rendah. 
Menurut Uno dan Soo, 1969 pertumbuhan larva udang galah dipengaruhi oleh temperatur, media, jenis pakan, intensitas cahaya, dan kualitas air.

Perkembangan seksual pada kematangan udang galah melibatkan proses fisiologis molting, pertumbuhan somatik dan perkembangan ovarium (Abowei dan Deekae 2010). Pertumbuhan dan frekuensi molting menjadi parameter pendukung yang dapat dikaitkan pada penelitian ini. Hasil pengamatan frekuensi molting pada udang galah yang diablasi menunjukkan bahwa perlakuan udang galah ablasi tanpa suplementasi vitamin E (UGA 0) ternyata mampu merangsang kuantitas ganti kulit dengan frekuensi molting tertinggi sebesar 2,00 kali $\pm 0,53$. Hal ini juga dibuktikan dengan pertumbuhannya yang menempati posisi tertinggi yaitu $2,45 \mathrm{~g} \pm 1,52$. Sehingga bila dihubungkan dengan penelitian penelitian sebelumnya, penelitian ini membuktikan terdapat keterkaitan antara frekuensi molting dan pertumbuhan udang galah.

Pertumbuhan udang akan terjadi setelah terjadinya pergantian kulit (Hadie et al, 2001). Ablasi unilateral dapat digunakan untuk mendorong pertumbuhan yang cepat dan pemijahan dalam spesies udang air tawar tertentu (Varalakshmi dan Reddy, 2010). Chakravarty (1992) melaporkan bahwa ablasi tangkai mata dapat merangsang molting dan mempercepat pertumbuhan udang galah jantan. Frekuensi molting juga tidak selalu berbanding lurus dengan laju pertumbuhan (Chen dan Chen, 2002). Pertumbuhan terkait dengan faktor luar dan dari dalam tubuh. Faktor luar diantaranya makanan dan lingkungan perairan meliputi temperatur, salinitas dan pH (Vijayan dan Diwan, 1995). Faktor dalam yakni kontrol hormon, dimana siklus molting pada udang berada dibawah kontrol hormon yang terdapat di mata.

Parameter lain yang mendukung penelitian ini adalah pengukuran kualitas air. Selama pemeliharaan pada kolam induk berada pada kisaran sesuai dengan standar. Kualitas air pada pemeliharaan larva juga perlu diperhatikan. Menurut FAO (2003) kualitas air mempunyai dampak yang sangat berpengaruh terhadap kesehatan dan penampilan larva. Rendahnya kualitas air pada media pemeliharaan dapat mengakibatkan pada rendahnya tingkat pertumbuhan, kelulushidupan, telatnya molting atau perubahan stadia, peningkatan bakteri epibion dan deformity. Kualitas air saat pemeliharaan larva diukur diawal pemeliharaan. Hal ini dapat menjadi salah satu penyebab rendahnya tingkat kelangsungan hidup larva, dikarenakan kualitas air yang tidak terkontrol. Namun kualitas air larva yang diukur saat awal pemeliharaan telah memenuhi standar yang ditetapkan. Temperatur pada saat pemeliharaan larva udang galah berkisar antara $30-31^{0} \mathrm{C}$ dan salinitas $12 \mathrm{ppt}$. Hal ini sesuai standar bahwa salinitas yang pada fase larva yakni 8-15 ppt (Ling, 1969). Menurut DKP (2009) salinitas yang baik untuk pemeliharaan adalah 12 ppt.

Informasi hasil penelitian ini menitikberatkan pada aspek induksi reproduksi Macrobrachium rosenbergii betina dengan kombinasi ablasi unilateral dan suplementasi vitamin E. Hal ini dapat dijadikan acuan sebagai salah satu upaya untuk memperkirakan potensi reproduksi induk udang yang dapat membantu dalam strategi pengelolaan budidaya udang galah. 


\section{Kesimpulan}

Berdasarkan penelitian yang telah dilakukan, dapat disimpulkan dosis optimum suplementasi vitamin E pada pakan sebesar 600 IU efektif untuk lama waktu matang gonad, IKG, fekunditas telur dan derajat kelangsungan hidup larva udang galah betina. Dosis optimum suplementasi vitamin E sebesar 600 IU efektif untuk lama waktu matang gonad, IKG, dan kelangsungan hidup larva pada udang galah betina yang diablasi unilateral. Suplementasi vitamin E sebesar 200 IU pada udang galah betina yang diablasi unilateral sudah menunjukkan fekunditas telur terbaik. Induksi reproduksi udang galah betina dengan kombinasi ablasi unilateral dan suplementasi vitamin E pada pakan sebesar $600 \mathrm{IU}$ efektif meningkatkan reproduksi udang galah.

\section{Daftar Pustaka}

Abowei, Deekae SN. 2010. The fecundity of Macrobrachium macrobrachion from Luubara Creek Ogoni Land, Niger Delta, Nigeria. International Journal of Animal and Veterinary Advances. 4: 148-154.

Ali F. 2001. Potensi dan peluang pengembangan udang galah di Indonesia. Prosiding: Workshop Hasil Penelitian Budi Daya Udang Galah Jakarta, 26 Juli 2001. Hal 14-17.

Bindu PR, Sahu L, Mohanty S, Vijaykhumar S. 2010. Effect of unilateral eyestalk ablation on ovarian maturation and occurrence of berried females in Macrobrachium rosenbergii (de Man). Indian J. Fish. 57(4): 77-80.

Cahu C, Fakhfakh M, Quazuguel P. 1991. Effect of Dietary a-tocopherol level on Reproduction of Penaeus indicus. In: P. Lavens, P. Sorgeloos, E. Jaspers \& F. Ollevier, editors. Larvi '91: Fish \& Crustasean Larviculture Symposium. European Aquaculture Society. 15: 242-244.

Cavalli RO, Tamtin M, Lavens P, Sorgeloos P, Nelis HJ, De Leenheer AP. 2001. The contents of ascorbic acid and tocopherol in the tissues and eggs of wild Macrobrachium rosenbergii during maturation. Journal of Shellfish Research. 20: 939-943.

Chakravarthy MS. 1992. Effect of eyestalk ablation on moulting and growth in prawn Macrobrachium rosenbergii. Indian J.Mar.Sci. 21: 287-289.

Chang. 1991. Crustasean Molting Hormones: Cellular effects, Role in Reproduction and Regulation by Molt Inhibiting Hormone. Frontiers of shrimp research. Edited by: DeLoach, P. F, Dougherty, W.J, Davidson, M.A. Elsevier, New York.

Chen SM, Chen JC. 2002. Effect of pH on survival, growth, molting, and feeding of giant freshwater prawns Macrobrachium rosenbergii. Aquaculture. 218: 613622.

DKP (Dinas Kelautan Perikanan). 2009. Standar Prosedur Operasional Pembenihan Udang Galah. Balai Besar Pengembangan Budidaya Air Tawar Sukabumi. Sub Unit Pembenihan Udang Galah,Sukabumi.

.FAO. 2003. Farming frshwater prawns: A Manual for the Culture of the Giant River Prawn (Macrobrachium rosenbergii). Food And Agriculture Organization of The United Nations, Rome.

Fulford. 2012. Fecundity and egg diameter of primiporous and multiporous blue crab callinecks sapidus (Brachyura: Portunidae) in Mississipi waters. Journal of Crustacean Biology. 32(1): 50-56. 
Hadie LE, Wartono H, Yayan H, Bambang G, Wakhid A. 2001. Prospek dan Peluang Usaha Budidaya Udang Galah. Prosiding: Workshop Hasil Penelitian Budi Daya Udang Galah Jakarta, 26 Juli 2001. Hal 41-44.

Hadie W dan Hadie LW 1984. Pengaruh pemotongan tangkai mata (ablasi) terhadap pertumbuhan juvenil udang galah (Macrobrachium rosenbergii). Jurnal Penelitian Perikanan Indonesia. 1(1): 37-43.

Halver JE. 1989. Fish Nutrition. Academic Press Inc, London.

Izquierdo MS, Fernandes-Palacios H, Talcon AGJ. 2001. Effect of broodstock nutrition on reproductive peformance of fish. Journal of Aquaculture. 197: 254.

Kovatcheva N, Kryhova N, Borisov R. 2009. Feeding Strategies For Early Life Stages of Red King Crab (Paralithodes camtschaticus) and Giant Freshwater Prawn (Macrobrachium Rosenbergii) Under Artificial Conditions. Larvi 2009, $5^{T H}$ Fish \& Shellfish Larviculture Symposium Ghent University, Belgium.

Lawrence. 1992. Reproduction of Penaeus Species in Captivuty. In:Marine Shrimp Culture:Principles and Practices, pp 93-170. Elsevier, Amsterdam.

Lavens P, Thongrad S, Sorgeloos P. 2002. Larval Prawn Feeds and the Dietary Importance of Artemia. Blackwell Science Company, London.

Ling SW. 1969. The General Biology and Development of Macrobrachium rosenbergii (De Man). FAO Fish. Rep. (57)3: 589-606.

Jufri, Marzuqi M, Giri NA, Kuma C. 1993. Pengaruh suplementasi vitamin E terhadap perkembangan gonad udang windu, Penaeus monodon asal tambak. J. Pen. Budidaya Pantai. 9(2): 117-126.

Murmu K, Sahu NP, Mallik SK, Reddy AK, Kohli MPS. 2007. Rematuration of spent Macrobrachium rosenbergii (de Man) female broodstock through dietary manipulation and eyestalk ablation. Israeli J. Aquacult. Bamidgeh. 59(2): 104110.

Naoaki T, Kim YK, Jasmani S, Ohira T, Aida K, Wilder MN. 2005. The dynamics of vitellogenin gene expression differs between intact and eyestalk ablated kuruma prawn (Penaeus Marsupenaeus japonicus). Journal of Fisheries Science. 71: 249-256.

Nazari EM, Simes-Costa, Muller MS, Ammar D, Dias, M. 2003. Comparisons of fecundity, egg size, and mass volume of the freshwater prawns Macrobrachium potiuna and Macrobrachium olfersi (Decapoda, Palaemonidae). Journal of Crustacean Biology. 23: 862-868.

New MB. 2002. Farming Freshwater Prawns: A Manual for Culture of The Giant River Prawn (Macrobrachium rosenbergii). Food and Agriculture Organization of The United Nations, Roma.

Nurdjana ML. 1986. Pengaruh Ablasi Mata Unilateral terhadap Perkembangan Telur dan Embrio Serta Kualitas Larva Udang Windu . Disertasi. Fakultas Pasca Sarjana Biologi, Universitas Gadjah Mada. Yogyakarta.

Okumura T. 2007. Effects of Bilateral and Unilateral Eyestalk Ablation on Vitellogenin Synthesis in Immature Female Kuruma Prawns, Marsupenaeus japonicus. Zoological Science. 233-240.

Pervaiz AP, Jhon SM, Sikdar-Bar M, Khan HA, Wani AA. 2011. Studies on the effect of unilateral eyestalk ablation in maturation of gonads of a freshwater prawn Macrobrachium dayanum. World Journal of Zoology. 6 (2): 159-163.

Racotta IS, Palacios E, Ibarra AM. 2003. Shrimp larval quality relation to broodstock condition. Aquaculture. 227: 107-130. 
Rao 1991. Reproductibe Biology of the Giant Freshwater Prawn Macrobrachium rosenbergii from Lake Koleru (Andhara Pradesh). Indian Journal of Animal Science. 61: 780-787.

Revathi P, Iyapparaj P, Munuswamy N, Krishnan M. 2012. Vitellogenesis during the ovarian development in freshwater female prawn Macrobrachium rosenbergii (De Man). International Journal of Aquatic Science. 3(2): 1-15.

Santos. 1998. Influencia da Ablacao Ocular no Camarao Macrobrachium rosenbergii, Sobre a Repraducao Epigmentacao Epidermica. Monografia de Gradaucao. Universidade Estadual Pauista. Jaboticabal.

Siahainenia L, Bengen DG, Affandi R, Wresdiyati T, Supriatna I. 2008. Studi Aspek Reproduksi Kepiting Bakau Melalui Percobaan Pembenihan dengan Perlakuan Ablasi Tangkai Mata. Journal of Ichtyos. 7(1): 55-63.

Subyakto S, Sakti I. 2012. Revitalisasi Tambak, KKP Pacu Produksi Udang. No.B.72/PDSI/HM.310/V/2012 Siaran Pers, Pusat Data Statistik dan Informasi-KKP.

Suwoyo D, Anindiastuti M, Soleh M, Gunarso A. 2001. Peningkatan produktivitas induk udang windu (Penaeus monodon Fab) dengan menggunakan bubuk paprika. Media Budidaya Air Payau Perekayasaan. 7: 1-11.

Tridjoko, Ismi S, Wardoyo, Suwirya K. 2001. Perbaikan mutu telur dengan suplemen vitamin E pada pakan induk ikan kerapu bebek (Cromileptes altivelis). Prosiding Seminar Riptek Kelautan Nasional. Balai Besar Riset Perikanan Budidaya Laut Gondol, Bali.

Uno Y, Soo Kl. 1969. Larval development of M. Rosenbergii (de Man) in the laboratory. Journal of Tokyo University of Fisheries. 55(2): 179.

Utomo N, Nurjanah, Setiawati M. 2006. Pengaruh pemberian pakan dengan konsentrasi vitamin $\mathrm{E}$ berbeda dan asam lemak N-3/N-6 1:2 terhadap penampilan reproduksi ikan zebra betina Brachydanio Rerio pra salin. Jurnal Akuakultur Indonesia. 5(1): 31-39.

Varalakshmi KN, Reddy R. 2010. Effects of eyestalk ablations on growth and ovarian maturation of the freshwater prawn Macrobrachium lanchesteri (de Man). Turkish Journal of Fisheries and Aquatic Sciences. 10: 403-410.

Venkitraman PR. 2010. Effect of eyestalk ablation on moulting and growth in penaeid prawns Metapenaeus monoceros. Indian J. Fish. 57(2): 25-32.

Vijayan KK, Diwan AD. 1995. Influence of temperature, salinity, $\mathrm{pH}$ and light on molting and growth in the Indian white prawn Penaeus indicus under laboratory conditions. Journal Asian Fisheries Science. 8: 63-72.

Watanabe T, Itoh C, Satoh S, Kitajima S, Fujita S. 1985. Effect of dietary protein levels and feeding period before spawning on chemical components of eggs Produced by red sea bream broodstock. Journal of Nippon Suisan Gakkaishi. 51: 15011509.

Yuwono E. 2005. Kebutuhan nutrisi crustasea dan potensi cacing lur (Nereis, Polychaeta) untuk akan udang. Jurnal Pembangunan Pedesaan. (1): 42-49. 